\title{
The Stock Market Response to CEO Changes: Does Gender Matter?
}

\author{
J. Christian Ola ${ }^{1} \&$ Dennis Proffitt ${ }^{2}$ \\ ${ }^{1}$ Business and Finance, Waynesburg University, Waynesburg, Pennsylvania, USA \\ ${ }^{2}$ Finance, Grand Canyon University, Phoenix, Arizona, USA \\ Correspondence: J. Christian Ola, Business and Finance, Waynesburg University, Waynesburg, Pennsylvania, \\ USA.E-mail: cola@waynesburg.edu
}

Received: February 13, 2015

Accepted: March 11, 2015

Online Published: April 20, 2015

doi:10.5539/ijbm.v10n5p1

URL: http://dx.doi.org/10.5539/ijbm.v10n5p1

\begin{abstract}
During the past 40 years, women's participation in the workforce has increased dramatically. However females have not made any recognizable gains when it comes to appointments as Chief Executive Officers (CEOs). In fact, the proportion of female CEOs heading publicly traded firms has stagnated at only $1.4 \%$.

This study analyzes the stock market response to both announcements and terminations of female CEOs. Most previous studies have been limited to the analysis of appointments only. Our results suggest that investor response to both appointments and terminations of female CEOs is not significantly different from that of male CEOs. The continued low proportion of female CEOs remains an enigma, and research investigating on other possible explanations for this phenomenon will have to be conducted.

The cultural composition of the business landscape in the United States continues to evolve. We've moved toward parity among the sexes in many areas. However the participation rate of females at the top level of business organizations remains low. Studies show that as few as 1.4\% of CEO's in the Fortune 500 are females and a mere $13 \%$ of corporate board members are women (Laff, 2007). This disparity also exists globally, as only 29 of the Forbes 100 Most Powerful Women in the World are CEOs (Atal, Perlroth, Vardi, \& Forbes, 2011).

Shareholders seek to maximize their wealth. The theoretical underpinnings of finance suggest that boards of directors and investors should be rational in their decision-making in order to provide the highest possible success for the firm. Females comprise as much as $50 \%$ of the modern-day U.S. workforce. Thus, one might think that the proportion of female CEOs and Board members would be closer to $50 \%$.

Surprisingly very few studies examine investor perceptions of CEO gender. Those that do analyze CEO appointments only and not terminations of CEOs (for example, Lee \& James, 2007; Martin, Nishikawa, \& Williams, 2009). In addition, findings from a variety of studies (reviewed in the next section) suggest that females may possess traits that make them better CEOs. Yet, the proportion of female CEOs and board members continues to lag.
\end{abstract}

Keywords: CEO changes, event studies, gender in business, female CEOs

\section{Gender-Based Differences in Behavior}

A large number of studies have examined gender-based differences in behavior. Findings from many of these indicate females may possess characteristics which would make them more effective CEOs than males (Note 1).

Dividing groups by gender is a natural tendency and perhaps the strongest method of human categorization (Fiske, Haslam, \& Fiske, 1991). Injunctive norms are easily triggered neurologically, and as a result, so are gender stereotypes (Banji \& Hardin, 1996). This strengthens the tendency for all people, including corporate boards of directors, to stereotype people by gender.

Risk Aversion. Beckmann and Menhkoff (2008) analyzed professional money managers and concluded that women may be less competitively oriented and significantly more risk adverse than their male counterparts in the money management field.

Data suggests that females are often appointed by firms with relatively high risk (total risk and idiosyncratic risk) in a possible attempt to lower the overall risk of the firm (Martin, Nishikawa, \& Williams, 2009). Other studies confirm that females are often perceived as more risk-averse than males (Oakley, 2000; Atkinson, Baird, \& Frey, 
2004; Lee \& James, 2007).

Studies also suggest that the appointment of a female CEO will influence the strategy and performance of a company, which may also have an impact on stock returns (Powell \& Ansic, 1997). However, other evidence suggests that the presence of a female CEO would have no impact whatsoever on the valuation of the company. Businesses run by women do not have a higher failure rate or generate lower earnings than businesses owned by men (Kallenberg \& Leicht, 1991).

Several studies seem to reaffirm the notion that loss aversion contributes to better investment success for women compared to men. Barber and Odean (2001) examined 35,000 U.S. households with active stock trading accounts from 1997 through 1997 . They found that men traded $45 \%$ more frequently than women, resulting in a net reduction in return for men of $2.65 \%$, while trading impacted women by only $1.72 \%$. Atkinson et al. (2003) reached similar conclusions. In fact, there is evidence to suggest that women are better long-term investors than men, as they take more time researching potential investments which often yield better returns (Lofton, 2011). A study of corporate boards used Tobin's Q to conclude that boards with two or more female members actually perform better than competing firms, and do not provide lower returns on assets (Carter, Simpkins, \& Simpson, 2003). Research conducted by the McKinsey Company on European firms suggests that gender diversity at the top-level, including CEOs and corporate boards, may attribute to approximately $48 \%$ higher earnings before interest and taxes, as well as a stock price that beat the market by 17\% (Buchanan, 2012).

Research from outside the business disciplines also suggests there are gender-based differences in risk aversion. An analysis of television game show behavior indicates that men have slightly higher average winnings, due to their desire to maximize winnings. Women participants seem to enjoy the participation in its entirety, and do not focus so strongly on profits (Johnson \& Gleason, 2009).

Another study examined daily-double betting on the game show Jeopardy in an attempt to determine the role of confidence in the decisions of contestants. The findings suggest that men tend to be more self-confident and aggressive, while women exhibit decision-making that is more consistent with loss-avoidance due to communal influences (He, Inman, \& Mittal, 2008).

Barber and Odean (2001) suggest men exhibit overconfidence, myopic loss-aversion, and mental accounting while these traits affect women less. However, other evidence indicates that females tend to succumb to communal influences in decision-making as opposed to overconfidence, often allowing for the benefits or losses to others impact their decision-making under uncertainty (Marco-Pallares, Kramer, Strehl, Shroder, \& Munte, 2010).

Despite these findings, there is evidence that a stereotype that boards with women on them indicate a company is doing poorly. One study of firms listed on the FTSE 100 found that firms possessing exclusively male board members enjoyed a $37 \%$ premium in valuation compared to firms that have female board members (Haslam, Ryan, Kulich, Trojanowski, \& Atkins, 2010).

Leadership Abilities. Zenger and Folkman (2012) provide evidence that females might be more effective managers than males. Their results indicate that female leaders are superior to males with regard to overall effectiveness (61\% compared to 52\%). They also concluded that females were superior in 12 of 15 leadership functions, with the largest differences found in self-development, integrity/honesty, and driving results.

Often an organization requires a transformational leader, which requires a future-oriented approach to managing in conjunction with the ability to foster relationships and commitments from followers as well as creatively shape the organization (Burns, 1978). Consider, for instance, former CEO of Delta Airlines, Michele Burns. Burns has continuously been called upon to lead organizations out of turbulent times, having guided Delta through the 9/11 attacks and leading Mirant out of Chapter 11 bankruptcy (Bingham \& Galagan, 2010). Burns directly attributes her success at Delta to fostering commitments from followers, and says "One of the primary reasons Delta was successful in negotiating through the $9 / 11$ crisis and positioning the company to survive and thrive was its ability to disperse leadership and engage a broad group of leaders."

Analysis indicates that females exhibit measurable traits that correspond with transformational leadership. These include traits such as examining problem-solving from unique angles, mentoring followers and acknowledging their needs, continual optimism and the ability to set new goals, and communicate the values, purpose and importance of the organization's mission (Eagly, 2007).

\section{Investor Response to Top Management Changes}

Studies examining gender. Martin, Nishikawa, and Williams (2009) analyzed the impact of gender on investor response to the hiring of a new CEO, as well as on the subsequent firm performance. Their study matched 70 
female CEO appointments with 70 male appointments. The samples were matched by industry. They concluded that investor response did not vary according to the gender of the CEO. Despite this, they found that female CEOs were more likely to reduce total risk, market risk, and firm-specific risk after their appointment.

Contrary to this finding, Lee and James (2007) found that firms appointing female CEOs experienced abnormal returns of $-3.5 \%$, while those appointing male CEOs had only a fraction of this response. Their sample consisted of only 17 firms, all with CEO appointments between 1990-2000. Multivariate regression was then utilized to analyze the roles of gender, age, insider/outsider, and industry experience in generating abnormal returns upon the announcement of a CEO change. The only variable they found to be significant was the gender of the new CEO.

Farrell and Hersch (2005) examined female vs. male appointments to the board of directors. They found that when a firm stock price performs well, they are more likely to find a female to join the board of directors as opposed to a male. The authors suggest that this may be the result of the low number of female candidates, which allows women to be more selective in the firms they join as board members.

Lucey and Carron (2011) examined the market response of firms listed on the FTSE 100 to changes in board composition, executive director, and CEO appointments. The results from the analysis suggest that there was no significant difference in abnormal return when appointing outside directors, and a small positive response was associated with the appointment of inside directors. Their results relating to gender are consistent with Lee \& James. They found that female executive director/CEO appointments generate negative abnormal returns, while female non-executive director appointments do not.

Studies examining factors other than gender. One of the seminal works concerning investor response to executive changes was conducted by Warner, Watts, and Wruck (1988). They found that, unless the share price of the firm was extremely positive or negative, no significant stock price reaction was noticeable as a result of top-management change.

Lubatkin et al. (1989) analyzed 477 firms that experienced a CEO change from 1971-1985 to determine if investors respond to the appointment of insiders differently than outsiders. They found that investors show preference for succession plans that integrate outsiders when the company is financially healthy (Lubatkin, 1989).

Mahajan and Lummer (1993) were among the early studies that examined both appointments and terminations. They analyzed 498 resignations and terminations of either the President of the firm, the CEO of the firm, or the board chairman for the period 1972-1983. The authors identified five separate types of action, ranging from firings, voluntary resignations, deaths, mandatory retirements, and reshuffles. The authors found significant negative returns for companies appointing insiders, while significant positive returns were associated with the death of executives (Mahajan \& Lummer, 1993).

Furtado and Rozeff (1987) reviewed board and executive appointments. They attempted to (1) measure the stockholder wealth effect of the appointments and (2) examine the impact of internal vs. external appointments. They found that internal appointments generated an abnormal return of $+0.51 \%$ as opposed to an abnormal return for outsider appointments of $-1.22 \%$.

Worrell (1986) and Worrell and Davidson (1987) examined investor response to the death of a CEO. The 1986 study found no significant returns were associated with the death of a CEO. Their 1987 study found that the appointment of external CEOs generated no significant abnormal returns, while the appointment of internal CEOs generated a positive abnormal return.

Chandy and Garrison (1991) also examined stock returns around the death of a CEO. Their findings indicate no significant abnormal returns around the date of death.

Reinganum (1985) analyzed internal and external appointments for new CEOs. What makes this study unique is that the author identifies either 'paired' changes or 'unpaired' changes. Paired changes are the events that include both the removal of the CEO and the simultaneous appointment of a new CEO, while an unpaired changed would include only the appointment of a new CEO. Positive abnormal returns were associated only with small firms that announced the removal of the current CEO in conjunction with the appointment of an external candidate (paired).

Furtado and Karan (1990) provide an extensive, but somewhat dated, review of top management changes that includes some of the articles mentioned previously. They discuss the causes of management change, the consequences of the changes, and the theoretical foundations for further studies. 


\section{Data}

Using event study methodology, we analyze the relationship between stock returns and the announcement of a CEO change. We start by identifying all CEO changes (both appointments and firings) of publicly-traded firms during the period between January 1, 2010 and December 31, 2012. The list came directly from Challenger \& Gray, a CEO outplacement firm and contributor to various media/business entities. Only unanticipated CEO changes that were not part of a planned strategic succession (this includes retirement, interim placement turning to permanent, or changes that were part of a merger or acquisition) were included. Planned successions were screened using the Thompson Reuter's news source.

Finally while no two exact times within the market can be perfectly compared, each of the firms being evaluated for this study were measured during a time when no stock split occurred, each CEO announcement was a surprise (fired, resigned, death, etc.), no merger or acquisition took place, and no surprise dividend occurred. As such, the firms were evaluated during a time when the market for the firm's stock was relatively calm and free from outside influence.

The resulting list consists of 206 CEO appointments and 261 terminations. Only 20 of the 206 CEO appointments were female. There were 23 female CEOs terminated during this study, out of 261 firings. The proportion of both female appointments and firings (8.8\% termination and 9.3\% appointments) far exceed the average number of female CEOs of publicly traded companies (USA Today, 2011).

Eight sectors of the S\&P 500 were represented in our sample. The sectors with the highest female representation were consumer products and media, comprising $22.2 \%$ and $20 \%$ respectively. The pharmaceutical industry and retail sector had the fewest female appointments.

A few previous studies found stock returns vary between inside and outside appointments. To control for this, the Mann Whitney Test for difference in means was conducted on the eleven day CARs (from t-5 to $t+5$ ) to determine if being an insider vs. an outsider was significant. We conducted separate tests for female and male cases. The results were not significant at the $5 \%$ level, indicating we could proceed by pooling inside and outside appointments (Note 2).

For each firm in our sample, normal returns were estimated using the single index market model and using cumulative data encompassing 255 trading days prior to the announcement. This is consistent with the literature. Next, abnormal returns were calculated by subtracting the normal returns from the actual results. These abnormal returns were then summed over an 11-day period (five day pre-announcement, day of announcement, and 5-day post announcement) to capture the cumulative abnormal returns for the stock. This practice was employed on every firm that experienced a CEO appointment or termination during the three year time interval.

Once firms had an abnormal return calculation, they were sorted according to A) the action of appointment or termination and then B) the gender of the CEO being examined. After the firms were sorted according to these two criteria, a series of statistical analysis was conducted including Welch's T-Test and the Mann-Whitney Test to measure differences in means between the appointed female CEO group and the appointed male CEO group, as well as the terminated female CEO group and the terminated male CEO group.

\subsection{Test Results-CEO Appointments}

We examine both CEO appointments and terminations, and test them separately. The first group examined was CEO appointments.

Descriptive statistics describing the returns from both male and female CEO appointments are contained in Table 1. Overall, the abnormal returns were positive for females and negative for males. Also, note the significant negative skewness of the returns from male appointments.

Table 1. Descriptive statistics for CEO appointments

\begin{tabular}{lll}
\hline & females & males \\
\hline Abnormal Return & 0.009 & -0.007 \\
Standard Deviation & 0.037 & 0.053 \\
Variance & 0.002 & 0.003 \\
Skewness & 0.769 & -2.473 \\
Anderson-Darling p-value & 0.165 & 0.005 \\
\hline
\end{tabular}


We test the following hypotheses:

H0: The common stock returns surrounding the appointment of a new CEO will not vary by the gender of the CEO.

Ha: The common stock returns surrounding the appointment of a new CEO will vary by the CEO's gender.

Cumulative Abnormal Returns (CARs) for appointed male and female CEOs were calculated over an 11 day event window. CARs for male and female appointments for each day in the 11-day event window were tested for statistical significance using a t-test. Table 2 presents the abnormal returns for male and female appointments as well as the t-test results for each day.

Table 2. Abnormal returns and T-Test results for appointed CEOs

\begin{tabular}{|c|c|c|c|c|c|c|c|c|c|c|c|}
\hline \multirow[b]{2}{*}{ Event Day } & \multicolumn{4}{|c|}{ Pre Event CAR } & \multicolumn{3}{|c|}{ Event } & \multicolumn{4}{|c|}{ Post Event CAR } \\
\hline & $\underline{-5}$ & $\underline{-4}$ & $\underline{-3}$ & $\underline{-2}$ & -1 & $\underline{\mathbf{0}}$ & $\underline{1}$ & $\underline{2}$ & $\underline{3}$ & 4 & $\underline{5}$ \\
\hline CAR for females & 0.009 & 0.014 & 0.008 & 0.006 & 0.008 & 0.004 & -0.005 & -0.012 & -0.011 & -0.004 & 0.008 \\
\hline CAR for males & 0.006 & 0.003 & -0.005 & 0.003 & 0.005 & -0.007 & -0.016 & -0.013 & -0.002 & -0.007 & -0.008 \\
\hline t-Stat & 0.494 & 1.363 & 0.818 & 0.188 & 0.219 & 0.844 & 0.654 & 0.119 & -0.83 & 0.3 & 0.998 \\
\hline T-Critical two -tail & 2.05 & 2.02 & 2.06 & 2.10 & 2.03 & 2.05 & 2.05 & 2.04 & 2.05 & 2.014 & 2.06 \\
\hline$P$ value & 0.625 & 0.181 & 0.421 & 0.82 & 0.83 & 0.41 & 0.52 & 0.91 & 0.41 & 0.77 & 0.33 \\
\hline Significant at .05 & No & No & No & No & No & No & No & No & No & No & No \\
\hline Significant at .10 & No & No & No & No & No & No & No & No & No & No & No \\
\hline
\end{tabular}

Use of the t-test requires that the data being tested be normally distributed. The Anderson-Darling test was used to determine whether our results fit this criterion. This tests for normality within the sample being analyzed, where:

H0: normally distributed.

Ha: non-normal distribution.

Critical value charts and p-values can be utilized just like normal distribution calculations. The equation for the Anderson Darling test is as follows:

$\mathrm{n}=$ sample size

$$
A D=-n-\frac{1}{n} \sum_{i=1}^{n}(2 i-1)\left[\ln F\left(x_{1}\right)+\ln \left(1-F\left(X_{n-i+1}\right)\right)\right]
$$

$\mathrm{F}(\mathrm{X})=$ cumulative distribution function for the normal distribution

$\mathrm{i}=$ the ith sample when the data is sorted in ascending order

The female CEO appointments reflect a p-value greater $>.05$ (.165), indicating a normal distribution. However, for male CEO appointments, a normal distribution did not exist as the p-value $<.05,(.005)$. The lack of normality for male returns indicates an alternative to the t-test should be used to test for statistical significance.

We use the Mann Whitney test for this purpose. This test is a non-parametric test that does not impose any distributional requirement. The results of this test are given in Table 3. They indicate that the mean abnormal return was not significantly different between males and females in any of the 11 days comprising the test period.

Table 3. Mann Whitney results for appointed CEOs

\begin{tabular}{lllllll}
\hline & \multicolumn{7}{c}{ Cumulative Mean Differences } \\
\hline & Event Day & Females & Males & Mean Diff & P-value & Significance \\
\hline Pre Event & -5 & -0.001 & -0.002 & -0.001 & 0.839 & No \\
& -4 & -0.002 & -0.003 & -0.003 & 0.718 & No \\
& -3 & -0.004 & -0.002 & 0.001 & 0.833 & No \\
& -2 & -0.003 & -0.001 & 0.002 & 0.805 & No \\
& -1 & 0.000 & 0.000 & 0.000 & 0.932 & No \\
Event Day & 0 & 0.008 & 0.002 & 0.006 & 0.491 & No \\
& 1 & 0.000 & 0.004 & -0.002 & 0.727 & No \\
& 2 & -0.005 & -0.002 & -0.001 & 0.839 & No \\
& 3 & -0.011 & 0.000 & -0.010 & 0.769 & No \\
& 4 & 0.000 & 0.000 & 0.000 & 0.932 & No \\
Post Event & 5 & 0.002 & -0.003 & 0.006 & 0.331 & No \\
\hline
\end{tabular}


These findings are contradictory to Lee and James (2003) who found that female CEOs generated a negative response from the market. Our study differs from Lee and James in two respects: (1) they used sample matching methods, while our data includes all CEO appointments during the time frame analyzed, and (2) Lee and James included appointments that were part of a succession plan, whereas we remove them from our data to control for this variable.

The positive return we find for females is consistent with Martin, et al. (2009). It is also consistent with the findings of Denis and Denis (1995), who observed positive abnormal returns when a female CEO was appointed to a firm.

\subsection{Test Results-CEO Terminations}

During the time period being analyzed, 261 CEOs were terminated. Included in that group were 23 females, while the remaining 238 were males. Some of the more publicized terminations from this group include the firing of Carol Bartz from Yahoo!, who was terminated via email, and Laura Hamilton at MTS Systems who resigned amid allegations of fraud and a federal investigation surrounding illegal exports. Additionally, Lisa Gersh was fired after serving only 7 months as CEO at Martha Stewart Living.

The second hypothesis examined is:

H01: The gender of a fired CEO will have no statistically significant impact on a company's stock price.

Ha1: The gender of a fired CEO will have a statistically significant impact on a company's stock price.

Descriptive statistics for the terminated CEO group are found in Table 4. Note

that, once again, the abnormal return for males is negative while that for females is positive. Note also that the distribution for both males and females is not normal, with females exhibiting significant positive skewness and males exhibiting significant negative skewness.

Table 4. Descriptive statistics for terminated CEOs

\begin{tabular}{lll}
\hline & female & male \\
\hline Abnormal Return & 0.007 & -0.008 \\
Standard Deviation & 0.072 & 0.061 \\
Variance & 0.005 & 0.004 \\
Skewness & 3.708 & -2.04 \\
Anderson-Darling p-value & 0.005 & 0.005 \\
\hline
\end{tabular}

Table 5 presents the abnormal returns by day, and the results of a t-test for significance in abnormal returns per day, for the terminated CEOs. Results of the t-test indicate that none of the days show a significant difference in the abnormal returns for males vs. females.

The results of the Anderson-Darling test for normality indicate both returns from male and female CEO terminations exhibit significant skewness. Given this result, the Mann Whitney test is appropriate for testing for significant differences between the two sets of returns. Results of the Mann Whitney test for CEO terminations are shown in Table 6.

Table 5. Abnormal returns and T-Test results for terminated CEOs

\begin{tabular}{|l|c|c|c|c|c|c|c|c|c|c|c|}
\hline & \multicolumn{3}{|c|}{ Pre - Event Abnormal Return } & \multicolumn{3}{c|}{ Event } & \multicolumn{3}{c|}{ Post Event Abnormal Return } \\
\hline Event Day & -5 & -4 & -3 & -2 & -1 & 0 & 1 & 2 & 3 & 4 \\
\hline Abnormal returns for females & -0.002 & -0.005 & 0.001 & -0.003 & -0.003 & 0.015 & 0.004 & -0.006 & -0.02 & 0.003 & 0.009 \\
\hline Abnormal returns for males & 0.004 & 0.005 & -0.008 & -0.005 & 0.002 & 0.01 & 0.012 & -0.006 & 0.005 & 0.008 & -0.007 \\
\hline t- stat & -0.89 & -1.46 & 1.16 & 0.282 & 0.548 & 0.558 & -0.817 & -0.071 & -1.296 & -0.58 & 1.48 \\
\hline T-critical two tail & 2.04 & 2.01 & 2.02 & 2.04 & 2.06 & 2.03 & 2.02 & 1.99 & 1.98 & 2.02 & 2.05 \\
\hline P-Value & 0.38 & 0.15 & 0.27 & 0.227 & 0.59 & 0.58 & 0.42 & 0.94 & 0.2 & 0.56 & 0.15 \\
\hline Significant at .05 & No & No & No & No & No & No & No & No & No & No & No \\
\hline Significant at .10 & No & No & No & No & No & No & No & No & No & No & No \\
\hline
\end{tabular}


Table 6. Mann Whitney results for CEO terminations

\begin{tabular}{|c|c|c|c|c|c|c|}
\hline & Event Day & $\begin{array}{l}\mathrm{N}=23 \\
\text { Females }\end{array}$ & $\begin{array}{l}\text { Daily Med } \\
\text { N=238 } \\
\text { Males }\end{array}$ & $\begin{array}{l}\text { n Differences } \\
\text { Median Diff }\end{array}$ & P-Value & Significance \\
\hline \multirow[t]{5}{*}{ Pre Event } & -5 & 0.007 & 0.000 & 0.007 & 0.180 & No \\
\hline & -4 & 0.010 & 0.004 & 0.008 & 0.210 & No \\
\hline & -3 & 0.001 & 0.000 & 0.002 & 0.820 & No \\
\hline & -2 & -0.004 & -0.001 & -0.006 & 0.380 & No \\
\hline & -1 & -0.007 & 0.000 & -0.001 & 0.810 & No \\
\hline \multirow[t]{5}{*}{ Event Day } & o & 0.010 & -0.002 & 0.008 & 0.400 & No \\
\hline & 1 & -0.013 & -0.003 & 0.002 & 0.880 & No \\
\hline & 2 & -0.019 & -0.004 & -0.005 & 0.722 & No \\
\hline & 3 & -0.011 & 0.000 & -0.010 & 0.178 & No \\
\hline & 4 & 0.000 & -0.003 & 0.009 & 0.915 & No \\
\hline Post Event & 5 & 0.000 & -0.003 & 0.002 & 0.772 & No \\
\hline
\end{tabular}

None of the 11 days revealed a significant difference in returns between male and female CEO terminations. This is consistent with our examination of CEO appointments discussed earlier, as well as with several past studies.

\section{Summary and Conclusions}

Notably, neither of our tests suggest a negative or positive bias toward gender. Instead, we find that investors view the appointment of a female CEO as slightly positive, while the appointment of a male CEO is slightly negative. This finding is contradictory to Lee and James (2003) who discovered a significant negative abnormal return when a female was appointed as CEO. Our results are consistent with Martin et al. (2009), who found a positive abnormal return for female appointments, and is also consistent with Denis and Denis (1995), who also found positive abnormal returns upon the appointment of a female CEO.

With regard to terminations, the tests indicate that investors have a slightly positive perception toward a firm that fires their female CEO and a slightly negative perception toward a firm that fires their male CEO. Neither result was statistically significant.

It is important to note that this study does not imply the hiring or firing of a CEO is not an important component of stock price. Rather, it should be interpreted as an indication that the role of gender is not significant.

Recent decades have seen unparalleled growth globally for the role of females in business. As such, one would suspect the role of CEO to become more inclusive of females. That has not been the case in the United States. Rather, most sources continue to reaffirm that approximately $1 \%-3 \%$ of all CEOs in the United States are females (Laff, 2007).

\section{Future Research}

During our research, we noted what appear to be some large increases in individual stock volume prior to the announcement of CEO appointments and terminations. This trait seemed prevalent whether the CEO was a female or a male. It stands to reason that further exploration in this area warrants consideration. Studies during the past two decades seem to suggest that in some instances, volume swells are reflective of speculative trades (Llorente et al., 2002.) Further, Wei (2006) hypothesizes that the upward trend and downward trend in individual stock share volatility in the long-run is fully accounted for by ROE volatility - both upward and downward (Wei et al., 2006). This deserves a closer look.

Several studies examine stock volume and insider trading activities. The current literature examines the release of information impacting stock price, but little information exists that explores the possibility that asymmetric information exists before the announcement of a CEO change.

\section{References}

Atkinson, S. M., Baird, S. B., \& Frey, M. B. (2003). Do female mutual fund managers manage differently? Journal of Financial Research, 1-18.

Banji, M. R., \& Hardin, C. D. (1996). Automatic stereotyping. Psychological Science, 7, 136-141.

Barber, B. M., \& Odean, T. (2001). Boys will be boys: Gender, overconfidence, and common stock investment. Quarterly Journal of Economics, 261-292.

Beckmann, D., \& Menhkoff, L. (2008). Will women really be women? Analyzing the gender difference among financial experts. Kyklos, 61(3), 364-384. http://dx.doi.org/10.1111/j.1467-6435.2008.00406.x

Bingham, T., \& Galagan, P. (2010). Trial by fire. $T+D, 64(9), 36-42$.

Buchanan, A. (2012). Follow the female leaders to faster portfolio growth. Retrieved May 1, 2012, from http://www.dailyfinance.com/2012/03/01/follow-the-female-leaders-to-faster-portfolio-growth/ 
Burns, J. M. (1978). Leadership: Harper \& Row.

Carron, B., \& Lucey, B. (2011). The effect of gender on stock price reaction to the appointment of directors: The case of the FTSE 100. http://dx.doi.org/10.2139/ssrn.1776202

Carter, D. A., Simpkins, B. J., \& Simpson, W. G. (2003). Corporate governance, board diversity, and firm value. Financial Review, 33-53.

Challenger, \& Gray. (2011). CEO changes during the past three years.

Chandy, P. R., \& Garrison, S. (1991). Top management relevance: the effect of key executive death on stock prices. Business Horizons, (June), 16-19.

Denis, D. J., \& Denis, D. K. (1995). Performance changes following top management dismissals. Journal of Finance, 1029-1057.

Eagly, A. (2007). Female leadership advantage and disadvantage: Resolving the contradictions. Psychology of Women Quarterly, 31, 1-12. http://dx.doi.org/10.1111/j.1471-6402.2007.00326.x

Farrell, K. A., \& Hersch, P. L. (2005). Addition to corporate boards: the gender effect. Journal of Corporate Finance, 11(1/2), 85-106. http://dx.doi.org/10.1016/j.jcorpfin.2003.12.001

Fiske, A. P., Haslam, N., \& Fiske, S. T. (1991). Confusing one person with another: What errors reveal about the elementary forms of social relations. Journal of Personality and Social Psychology, 60, 656-674. http://dx.doi.org/10.1037/0022-3514.60.5.656

Furtado, E. P., \& Karan, V. (1990). Causes, consequences, and shareholder wealth effects of management turnover: A review of empirical evidence. Financial Management, 60-75.

Furtado, E. P., \& Rozeff, M. S. (1987). The wealth effects of company initiated management changes. Journal of Financial Economics, 18, 147-160.

Haslam, S. A., Ryan, M. K., Kulich, C., Trojanowski, G., \& Atkins, C. (2010). Investing with prejudice: The relationship between women's presence on company boards and objective and subjective measures of company performance. British Journal of Management, 21, 484-497. http://dx.doi.org/10.1111/j.1467-8551.2009.00670.x

He, X., Inman, J. J., \& Mittal, V. (2008). Gender Jeopardy in financial risk taking. Journal of Marketing Research, 17, 414-424. http://dx.doi.org/10.1509/jmkr.45.4.414

Johnson, D. K., \& Gleason, T. R. (2009). Who really wants to be a millionaire? Gender differences in game show contestant behavior under risk. Social Science Quarterly, 90(2), 243-261. http://dx.doi.org/10.1111/j.1540-6237.2009.00615.x

Kallenberg, A. L., \& Leicht, K. T. (1991). Gender and organizational performance: Determinants of small business survival and success. Academy of Management Journal, 131-161. http://dx.doi.org/10.2307/256305

Laff, M. (2007, March). The Invisible Wall. $T+D, 61(3), 32-38$.

Lee, P. M., \& James, A. H. (2007). She-e-os: Gender effects and investor reactions to the announcements of top executive appointments. Strategic Management Journal, 227-241.

Llorente, G., Michaely, R., Saar, G., \& Wang, J. (2002). Dynamic volume-return relation of individual stocks. Review of Financial Studies, 15, 1005-1047.

Lofton, L. (2011). Warren Buffett invests like a girl and why you should, too. New York, NY: Harper Collins Publishers.

Lubatkin, M. H., Chung, K. H., Rogers, R. C., \& Owers, J. E. (1989). Stockholder reactions to CEO changes in large corporations. Academy of Management Journal, 32(1), 47-68. http://dx.doi.org/10.2307/256419

Mahajan, A., \& Lummer, S. (1993). Shareholder wealth effects of management changes. Journal of Business Finance \& Accounting, 20(3), 393-410.

Mann, H. B., \& Whitney, D. R. (1947). On a test of whether one of two random variables is stochastically larger than the other. Annals of Mathematical Statistics, 18(1), 50-60. http://dx.doi.org/10.1214/aoms/1177730491

Martin, A. D., Nishikawa, T., \& Williams, M. (2009). CEO gender: Effects on valuation and risk. Quarterly Journal of Finance and Accounting, 48(3), 23-40. http://dx.doi.org/1939.8123/09/1300-00023

Oakley, J. G. (2000). Gender-based barriers to senior management positions: Understanding the scarcity of 
female CEOs. The Journal of Business Ethics, (October), 321-334.

Powell, M., \& Ansic, D. (1997). Gender differences in risk behaviour in financial decision-making: An experimental analysis. Journal of Economic Psychology, (November), 605-628. http://dx.doi.org/10.1016/S0167-4870(97)00026-3

Reinganum, M. R. (1985). The effect of executive succession on stockholder wealth. Administrative Science Quarterly, 30, 46-60.

Warner, J. B., Watts, R. L., \& Wruck, K. H. (1988). Stock prices and top management changes. Journal of Financial Economics, 20, 461-492.

Wei, S. X., \& Zhang, C. (2006). Why did individual stocks become more volatile? The Journal of Business, 79(1), 259-292.

Welch, B. L. (1947). The generalization of "student's" problem when several different population variances are involved. Biometrika, 34, 28-35. http://dx.doi.org/10.1093/biomet/34.1-2.28

Worrell, D. L., \& Davidson III, W. N. (1987). The effect of CEO succession on stockholder wealth in large firms following the death of a predecessor. Journal of Management, 13(3), 509-515.

Worrell, D. L., Davidson, W. N., Chandy, P. R., \& Garrison, S. L. (1986). Management turnover through deaths of key executives: Effects on investor wealth. Academy of Management Journal, 29(4), 674-694. http://dx.doi.org/10.2307/255939

Zenger, F. (2012). A study in leadership: Why women do it better than men.

\section{Notes}

Note 1. A complete review of this literature is beyond the scope of this paper. Our goal is to review the most widely-cited evidence that relates directly to our topic.

Note 2. These results are available from the authors.

\section{Copyrights}

Copyright for this article is retained by the author(s), with first publication rights granted to the journal.

This is an open-access article distributed under the terms and conditions of the Creative Commons Attribution license (http://creativecommons.org/licenses/by/3.0/). 